\title{
Increasing Water System Robustness in the Netherlands: Potential of Cross-Sectoral Water Reuse
}

\author{
G. J. Pronk ${ }^{1}$ (D) . S. F. Stofberg ${ }^{1}$ - T. C. G. W. Van Dooren ${ }^{1}$ - M. M. L. Dingemans ${ }^{1,2}$. \\ J. Frijns ${ }^{1}$ - N. E. Koeman-Stein ${ }^{1}$ - P. W. M. H. Smeets ${ }^{1} \cdot$ R. P. Bartholomeus ${ }^{1,3}$
}

Received: 24 March 2021 / Accepted: 20 July 2021 / Published online: 17 August 2021

(C) The Author(s) 2021

\begin{abstract}
Water reuse has the potential to substantially reduce the demand on groundwater and surface water. This study presents a method to evaluate the potential of water reuse schemes in a regional context and demonstrates how water reuse propagates through the water system and potentially reduces pressure on groundwater resources. The use of Sankey diagram visualisation provides a valuable tool to explore and evaluate regional application of water reuse, its potential to reduce groundwater and surface water demand, and the possible synergies and trade-offs between sectors. The approach is demonstrated for the Dutch anthropogenic water system in the current situation and for a future scenario with increased water demand and reduced water availability due to climate change. Four types of water reuse are evaluated by theoretically upscaling local or regional water reuse schemes based on local reuse examples currently in operation in the Netherlands or Flanders: municipal and industrial wastewater effluent reuse for irrigation, effluent reuse for industrial applications, and reuse for groundwater replenishment. In all cases, water reuse has the potential to significantly reduce groundwater extraction volume, and thus to alleviate the pressure on the groundwater system. The water-quantity based analysis is placed in the context of water quality demands, health and safety aspects, technological requirements, regulations, public perception, and its net impact on the environment. This integrative context is essential for a successful implementation of water reuse in practice.
\end{abstract}

Keywords Water stress $\cdot$ Water reuse $\cdot$ Water system robustness $\cdot$ Wastewater

G. J. Pronk

geertje.pronk@kwrwater.nl

1 KWR Water Research Institute, PO box 1072, NL-3430BB Nieuwegein, Netherlands

2 Institute for Risk Assessment Sciences (IRAS), Utrecht University, Utrecht, Netherlands

3 Soil Physics and Land Management, Wageningen University \& Research, Wageningen, Netherlands 


\section{Introduction}

Population growth and a growing economy result in increasing resource demands, including water, whereas climate change is leading to increasing uncertainty for the availability of conventional water resources like groundwater, surface water and precipitation (Vörösmarty et al. 2000; McDonald et al. 2011). In many regions of the world, groundwater overexploitation is a major risk for future water security (De Graaf et al. 2019). For the Netherlands specifically, in the western low-lying areas there is an increasing need to counteract groundwater salinization, while in the eastern region upland areas a decreasing groundwater table has led to damage in agricultural and natural areas. Next to that, resilient management of drinking water resources is becoming increasingly important due to changes in the economic situation and the population (Kloosterman et al. 2021). Together with the current drive towards a circular economy, this urges the continued exploration of the potential and applicability of (treated) effluent as an alternative water source, i.e. wastewater reuse. However, there is still a knowledge gap between site-based experimental (pilot) studies and the translation of their potential contribution to the water supply of a city or region at a system-level (Liu et al. 2020).

In this manuscript, we explore the potential of water reuse to contribute to increased water system robustness, i.e. the extent to which a water system can keep performing under increasing stress (Makropoulos et al. 2018). We define the anthropogenic freshwater system as the part of the water system for human use, e.g. drinking water production, industry, urban areas, agriculture (irrigation) and wastewater treatment. The implementation of water reuse can potentially connect these anthropogenic water flows to create a more circular water system that is less reliant on groundwater and surface water sources.

Water reuse is an important solution to manage water scarcity (Hochstrat et al. 2006; European Commission 2020). It has been successfully implemented at a local level for municipal wastewater for drinking water, industry, agriculture and horticulture in Europe (e.g. Bontoux and Courtois 1996; Devaux et al. 2001; Giannoccaro et al. 2019; Pintilie et al. 2016; Ternes et al. 2007) and more specifically in the Netherlands and Flanders (Majamaa et al. 2010; Zuurbier et al. 2018). The number of reuse initiatives may further increase after the implementation of new European Commission (EC) legislation on minimum requirements for water reuse in agriculture (European Commission 2020).

Regional strategies for implementation of water reuse can be challenging to develop, as responsibility for the availability and demand of water lies with different parties across sectors and depends on location and timing. Connections within the freshwater system and other environmental systems are often not obvious, and the application of water reuse at one place may affect the water availability at another location, e.g. by diverting base flows of small effluent fed streams. To determine the potential of water reuse for different types of water reuse applications, their trade-offs and benefits, and the magnitude of their contribution to the fresh water supply on a regional or national level, an evaluation framework is needed (Dingemans et al. 2020; Liu et al. 2020). Kloosterman et al. (2021) demonstrated a decision framework that considered water quantity, water quality and the environmental impact of the water resources could be used for resilience enhancing design of (drinking) water resources. Consideration of these kind of interdependencies is necessary to achieve an overall more robust freshwater system. Furthermore, the quantitative 
aspects, consequences, opportunities, and risks with regard to water quality and impact on surrounding ecosystems must be addressed (Dingemans et al. 2020). As such, these aspects place the implementation of regional water reuse in an interdisciplinary context that requires effective coordination across sectors.

This study presents a method to evaluate the potential contribution of water reuse (or other alternative water sources) to reducing pressure on groundwater at a system-level, with the Netherlands as an example. This approach provides a high-level assessment method that can be used by stakeholders and decision makers to identify opportunities for water reuse in their region, consider potential synergies or trade-offs, and provide a starting point for more detailed analysis. Simulations are based on the present day situation, as well as a future (2050) scenario that assumes an increased water demand due to population growth, a growing economy, as well as a limited water availability due to climate change. Four types of water reuse are evaluated by theoretically upscaling local or regional water reuse schemes based on local reuse examples currently in operation in the Netherlands or Flanders. The potential of the four pilots to reduce the pressure on groundwater and to increase water system robustness on a national level is assessed. The results are visualized in Sankey diagrams that provide an easy assessment tool for the quantitative potential of wastewater reuse in a region. With an overview of the results from the Sankey diagrams, the most important opportunities and barriers for implementation of water reuse are discussed.

\section{Materials and Methods}

\subsection{Sankey Diagrams}

Sankey diagrams were developed to visualize energy flows, but can also be used to provide insight into the distribution of water in a water system (Curmi et al. 2013). Here, Sankey diagrams were developed to summarize annual water flows (links) between reservoirs (nodes) for the anthropogenic water system of the Netherlands, and to analyse and visualise the propagation of the impact of water reuse throughout the water system. The quantitative data of the water flows is expressed by the size of the arrows. Arrow colour expresses a qualitative measure of water quality. Quantitative data (million $\mathrm{m}^{3} \mathrm{y}^{-1}$ ) was collected from literature (2015 - 2019, see scenarios) for the main anthropogenic water flows within agriculture and horticulture industries, as well as households and businesses.

Much of the official data sources (Dutch national statistics) are based on surveys - as such, samples contain uncertainties and not all data is based on the same measurement year. Some data sources may not match others due to different methodologies. In addition, the anthropogenic water system is not a closed system, and water flows can be affected in specific cases, e.g. by rainwater that enters the sewage system. If known, these cases are included in the results. In some cases, water flows were estimated due to a lack of information. The data sources and assumptions for each node and link are described in detail in Supplementary Information 1.

\subsubsection{Current Water System}

For the current water system of the Netherlands, data sources include the input and output of the National Water Model (NWM; Hunink et al. 2018). For water flows to and from the industrial sector, data was obtained from Graveland et al. (2017), Van der Aa et al. (2015), 
and Vewin (2017). CBS Statline (2019) were consulted for flows not considered by the aforementioned sources. The data sources and assumptions are discussed in detail in Supplementary Information 1.

\subsubsection{Future Water System Under Pressure}

Several scenarios for the future water system of the Netherlands are available as part of the national Delta-programme (Wolters et al. 2018). For this study we selected a scenario that simulates high pressure on the water system due to climate change as well as high increase in water demand due to economic growth and population growth, which is referred to as STOOM ('steam') (Hunink et al. 2018). The outcomes of this simulation model the largest realistic changes that were expected at the time of scenario development in 2017.

The following assumptions were made for water flows absent in the STOOM-scenario: (I) The use of surface water for drinking water production, the use of drinking water, and the production of wastewater by households and businesses grows proportionally with the estimated increase of groundwater abstractions for drinking water production; (II) The STOOM-scenario suggests an increase of groundwater abstractions for the production of industrial process water. This relative estimated increase of $15 \%$ was applied to the reference situation from Graveland et al. (2017); (III) the industrial use of drinking water and surface water, and the consequent disposal of industrial wastewater to surface water and wastewater treatment plants (WWTPs) are assumed to grow proportionally.

\subsubsection{Water Reuse Applications}

The Sankey diagram for the future water system of the Netherlands under pressure (STOOM-scenario) was extrapolated to illustrate and assess the potential impact of four different types of water reuse applications on water system robustness. For clarity, one type of reuse is extrapolated per case (Table 1). In reality, a regional strategy would include a mixture of different types of water reuse in combination with other methods (e.g. use of conventional water sources, rainwater harvesting, water conservation measures, etc.).

For all scenarios, water losses can occur during treatment of reused water, which depend on the water quality requirements and selected treatment technology and thus differ per application. These aspects are not considered in detail in this study, but in general, the impact of water losses during purification is expected to be small when considered in the context of

Table 1 Extrapolated water reuse cases, local examples, and references

\begin{tabular}{|c|c|c|c|}
\hline & Reuse type & Example case & Reference \\
\hline A & $\begin{array}{l}\text { Reuse of municipal WWTP-effluent for } \\
\text { (subsurface) irrigation in agriculture and } \\
\text { horticulture }\end{array}$ & $\begin{array}{l}\text { Haaksbergen, subsur- } \\
\text { face irrigation for } \\
\text { agriculture }\end{array}$ & (Narain et al. 2020) \\
\hline B & $\begin{array}{l}\text { Reuse of industrial effluent for irrigation (with } \\
\text { possible addition of subsurface storage) }\end{array}$ & $\begin{array}{l}\text { Dinteloord, horti- } \\
\text { culture }\end{array}$ & (Zuurbier et al. 2018) \\
\hline $\mathrm{C}$ & Reuse of WWTP-effluent for industry & $\begin{array}{l}\text { Terneuzen, DOW } \\
\text { Benelux B.V }\end{array}$ & $\begin{array}{l}\text { (Majamaa et al. 2010; } \\
\text { Koeman-Stein et al. 2016) }\end{array}$ \\
\hline $\mathrm{D}$ & $\begin{array}{l}\text { Reuse of WWTP-effluent for groundwater } \\
\text { replenishment and subsequent drinking water } \\
\text { production }\end{array}$ & $\begin{array}{l}\text { Torreele, dune infil- } \\
\text { tration and drinking } \\
\text { water production }\end{array}$ & (Van Houtte et al. 2012) \\
\hline
\end{tabular}


the entire water system. However, losses for certain techniques like ultra-filtration (UF) and reverse osmosis (RO) can be significant (Metcalf and Eddy Inc. et al. 2013). Water quality requirements vary widely between applications and between different steps in production processes, in particular in industry and agriculture. In this study, water quality requirement is generalized following the 'fit for purpose' principle. This means that the quality and safety standards required, as well as potential human exposure routes for the specific intended use of the water should be taken as a basis to determine the purification level required. For the Sankey diagrams in the current study, the water quality related to the dominant application within the sector considered is indicated.

The magnitude of the reuse water flow for the reuse scenarios (Table 1) was determined by the smallest of either: the amount of available water from the specified source, and the water demand of the specified sector. For reuse of WWTP-effluent for groundwater replenishment and subsequent drinking water production (scenario D), the amount of WWTPeffluent that is reused for groundwater replenishment is assumed to be equal to the groundwater that is extracted in the whole anthropogenic water system (for all purposes, not only for drinking water production). This strategy differs from the other scenarios, where the impact of the water reuse flow is focused on application in a specific sector only. The assumptions of the extrapolated reuse cases are further clarified in Supplementary Information 1.

\section{Results and Discussion}

\subsection{Reference Scenario: Current Water System and Assumptions}

In the Netherlands, drinking water is produced from both groundwater and surface water. Drinking water is consumed and used in households and businesses, eventually leading to wastewater that, together with rainwater collected on roofs and paved surfaces, is collected in the sewage system as communal wastewater and discharged to WWTPs. Households not connected to the central sewer system comprise less than $1 \%$ of the total wastewater flow from households (Partners 4 Urban Water and Deltares 2020), and are not considered in this study. The direct use of groundwater and precipitation by households is uncommon in the Netherlands. The industrial sector requires process water and cooling water, which are produced from groundwater, surface water, or drinking water, and discharged after use to surface water bodies directly or after treatment by municipal or industrial WWTPs. Cooling water accounts for a flow that approximately equals the sum of all other anthropogenic flows. For reasons of readability this flow was omitted from the figures in this manuscript. The anthropogenic freshwater flows within the current water system of the Netherlands including cooling water are given in the Supplementary Information 2.

For the current water system excluding cooling water (Fig. 1A), industrial wastewater discharged to surface water is calculated as the difference between total industrial wastewater discharged to surface water and industrial cooling water used for industry. The assumptions and uncertainty in the data resulted in a small imbalance in some nodes of the Sankey diagrams. However, overall the diagrams represent a simplified but clear visualization of the quantitative water system. The volume of industrial wastewater may be greater than that of process water, since water can also be produced in industrial processes, for example in the processing of sugar beets, potatoes, milk or cheese (Stofberg et al. 2019). WWTPs treat communal and industrial wastewater, (partially) removing several contaminants, and 

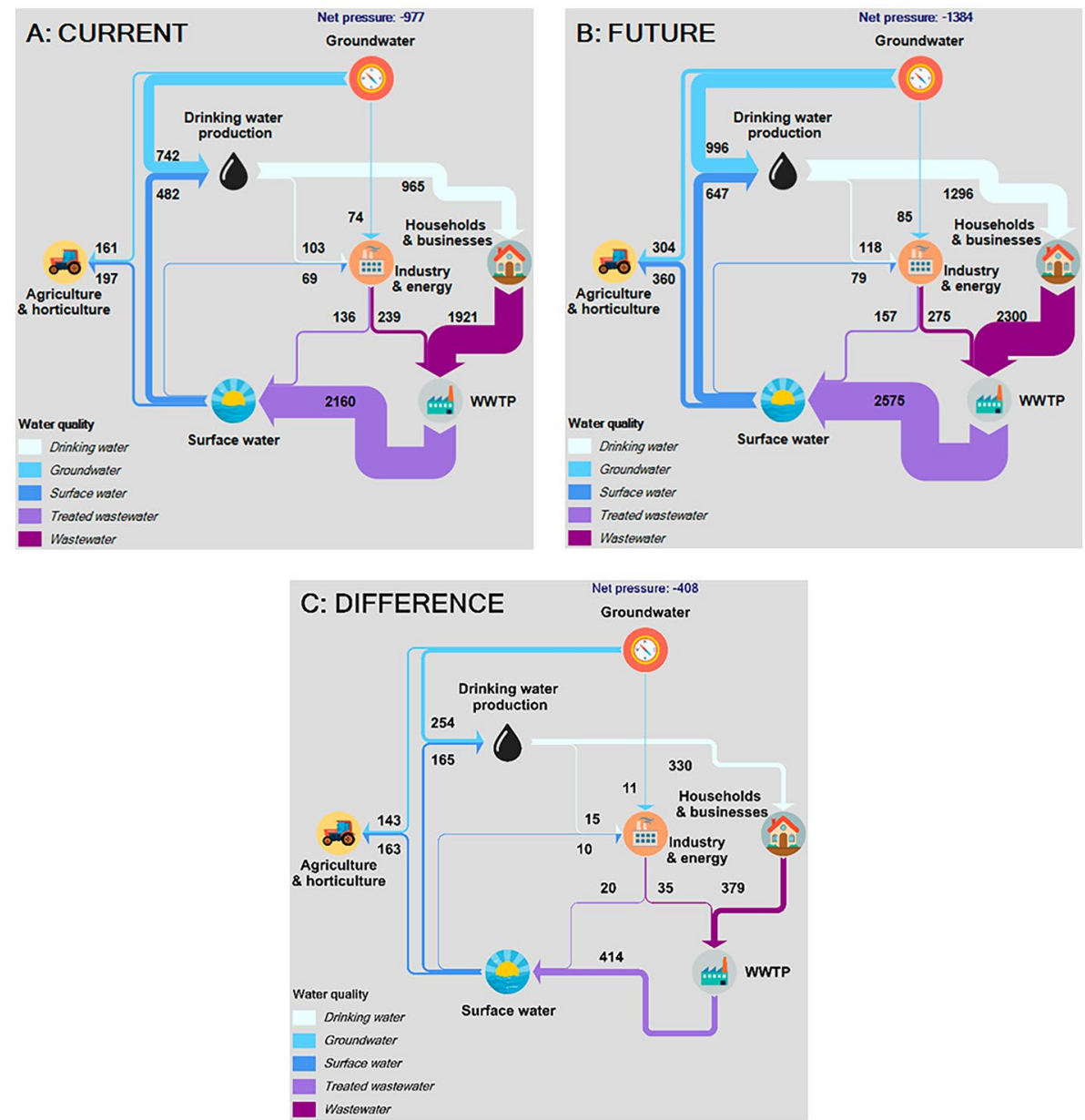

Fig. 1 Anthropogenic water system of the Netherlands for the current situation A and the future situation according to the STOOM-scenario B, both excluding cooling water, with the flows and the net pressure on the groundwater system given in million $\mathrm{m}^{3} \mathrm{year}^{-1}$. The sources and assumptions are given in the main text and in SI 1, and are omitted here for readability. The difference between the future and current anthropogenic water system $\mathrm{B}-\mathrm{A}$ is given in $\mathrm{C}$. Note that rounding errors have resulted in small inconsistencies

usually discharge the effluent to surface waters. Water losses in the form of concentrated waste streams (e.g. WWTP sludge or RO concentrate) were not considered. Therefore, it is assumed that effluent quantitatively equals influent. Drinking water losses during distribution in the Netherlands are $<6 \%$, and were not further considered (Vreeburg et al. 2013; Vewin 2017). Agricultural and horticulture sectors use both groundwater and surface water for the irrigation of crops in the growing season. As the Sankey diagrams are of the anthropogenic water system, water use for agriculture in the diagrams only includes irrigation from groundwater and surface water. Precipitation and evapotranspiration in agricultural systems are not included as water flows.

The net pressure on groundwater for the current anthropogenic water system equals 977 million $\mathrm{m}^{3}$ year $^{-1}$ (Fig. 1A). Figure 1B shows the increased pressure on the future 
water system of the Netherlands under the STOOM scenario, while the difference between the two scenarios is highlighted in Fig. 1C. Under the STOOM scenario, population growth and increasing economic activity result in a higher demand for industrial products and energy, and therefore a higher water demand. The scenario assumes an increase in water demand for all sectors, which results in a general increase in water fluxes. Most notable for the purpose of this study is the increase in groundwater exploitation, i.e. in the net pressure on the groundwater system (Table 2), and the increase in the flow of treated wastewater from 2160 to 2575 million $\mathrm{m}^{3} \mathrm{y}^{-1}$ (Fig. 1B and C).

The Sankey diagrams provide an overview of the anthropogenic water system, its main water flows and their relative magnitude. However, the considerations around cooling water and losses due to water treatment demonstrate the complexity and variety in water uses and their effect on the water system. Here, the Sankey diagrams are used at a high abstraction level for the entire country of the Netherlands. When applied in practice for use in a specific region, a careful consideration and analysis is needed to ensure that the required processes and level of detail are included.

\subsection{Water Reuse - Matching Water Availability and Demand}

The four example implementation scenarios for water reuse and their effect to alleviate the pressure on groundwater resources (Fig. 2) demonstrate the potential impact of water reuse on the water system by modelling the scaling-up of current pilot applications. This allows a comparison of differences in water flows and net pressure on groundwater resources between water reuse scenarios (Fig. 2), with the reference situation (Fig. 1A) and the STOOM-scenario without water reuse (Fig. 1B). All reuse cases show a significant reduction in pressure on groundwater relative to the STOOM scenario (Table 2). However, with the exception of case D (reuse of WWTP-effluent for groundwater replenishment and subsequent drinking water production), the future pressure on the groundwater system would still be higher than in the current situation. This underlines that these reuse cases have to be part of a larger set of measures to completely address the pressure on the groundwater system.

The reuse scenarios can fulfil the water demand to different extents, and each have their own effect on the water system. Reuse of WWTP-effluent has the potential to completely fulfil the irrigation water demand of agriculture and horticulture (Fig. 2A). However, this results in a considerably reduced flow of effluent to surface water compared to the reference

Table 2 Relative change in groundwater pressure under each scenario

\begin{tabular}{|c|c|c|c|}
\hline & \multirow[t]{2}{*}{ Reuse type } & \multicolumn{2}{|l|}{ Groundwater pressure } \\
\hline & & $\begin{array}{l}\text { Reduction due to reuse } \\
\text { under STOOM }(\%)\end{array}$ & $\begin{array}{l}\text { Relative to refer- } \\
\text { ence scenario }(\%)\end{array}$ \\
\hline A & $\begin{array}{l}\text { Reuse of WWTP-effluent for (subsurface) irrigation in } \\
\text { agriculture and horticulture }\end{array}$ & $-22 \%$ & $+11 \%$ \\
\hline B & $\begin{array}{l}\text { Reuse of industrial effluent for irrigation (with pos- } \\
\text { sible addition of subsurface storage) }\end{array}$ & $-14 \%$ & $+22 \%$ \\
\hline $\mathrm{C}$ & Reuse of WWTP-effluent for industry & $-12 \%$ & $+24 \%$ \\
\hline $\mathrm{D}$ & $\begin{array}{l}\text { Reuse of WWTP-effluent for groundwater replenish- } \\
\text { ment and subsequent drinking water production }\end{array}$ & $-100 \%$ & 0 \\
\hline
\end{tabular}



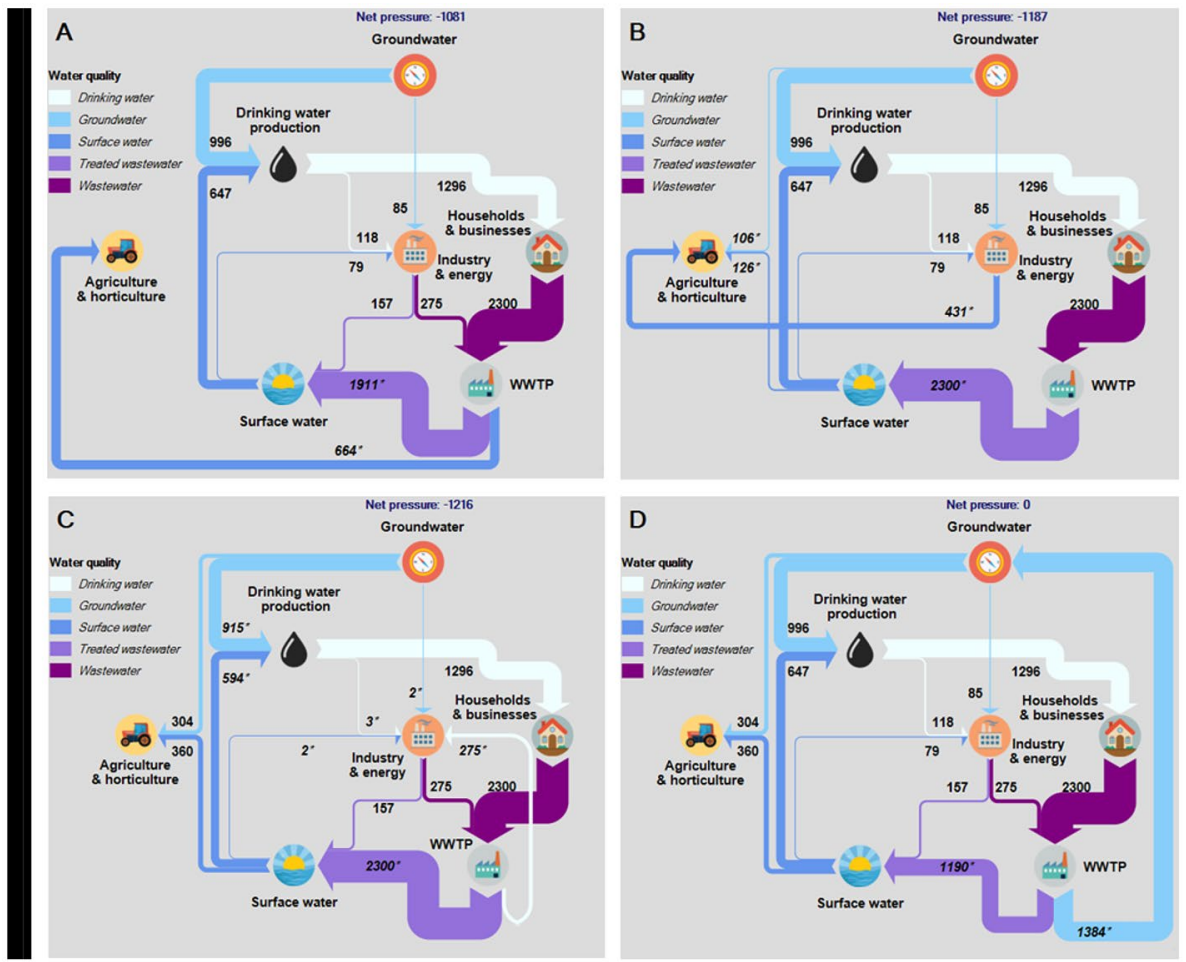

Fig. 2 Water system of the Netherlands excluding cooling water for four different water reuse scenarios: Reuse of WWTP-effluent for irrigation A, reuse of industrial effluent for irrigation $\mathbf{B}$, reuse of WWTPeffluent for industry $\mathbf{C}$, reuse of WWTP-effluent for groundwater replenishment $\mathbf{D}$. The flows and the net pressure on the groundwater system are given in million $\mathrm{m}^{3}$ year $^{-1}$. The sources and assumptions are given in the main text and in SI 1 and are here omitted for readability. Flows affected by the water reuse are given in italics and marked with an asterisk

situation (10\%), which may lead to reduced flows in some streams that are dependent on effluent. On the other hand, the reduced emission of effluent from WWTPs may lead to improved surface water quality (Eggen et al. 2014).

Reuse of industrial wastewater (Fig. 2B) cannot completely fulfil the irrigation water demand of agriculture and horticulture, and ground- and surface water, or alternative measures will be required to completely fulfill demand. In addition, decoupling industrial wastewater from WWTPs causes the discharge of WWTP-effluent to surface water to decrease by $16 \%$ compared to the STOOM-scenario. The example in Fig. $2 \mathrm{~B}$ is based on the application of water reuse in horticulture after subsurface storage (Zuurbier et al. 2018). Since the requirement of high-purity water for horticulture and subsurface storage is not a general requirement in agriculture and horticulture it is not shown here, but this could be evaluated in a fit for purpose design.

For industry process water needs, Fig. $2 \mathrm{C}$ shows that recirculation of industrial waste water is just short of covering demand. However, if other effluent sources are included this would be sufficient to fulfil the demand (Fig. 2C). Reuse of industrial waste water results in reduced pressure on groundwater as well as surface water and drinking water production 
under STOOM. Discharge of industrial wastewater and WWTP-effluent to surface water decreases by approximately $10 \%$ compared to the STOOM-scenario without water reuse.

The infiltration of WWTP-effluent for groundwater replenishment and subsequent drinking water production (Fig. 2D) requires a different approach. Infiltration of WWTP-effluent has the potential to fully alleviate the quantitative pressure on the groundwater system. The infiltrated water can subsequently be used for drinking water production, but may also provide additional resources for agriculture and industry which may improve natural areas suffering from groundwater depletion, and can help prevent groundwater salinization (Dillon et al. 2019). Discharge of WWTP-effluent to surface water, however, strongly decreases compared to both the STOOM-scenario (-54\%) and the current situation (-45\%), which can affect other purposes of surface water use. Large-scale effluent infiltration may also affect soil and groundwater quality, as purified effluent may still have a different composition from natural surface or rain water leading to unintentional changes in subsurface chemistry. Groundwater replenishment does result in an increased feed of groundwater to surface water bodies in the form of baseflow (Kourakos et al. 2019), which could partially alleviate the decrease in fresh water supply from WWTP-effluent flowing directly to surface water. However, this can still be a major concern especially for small, currently effluent fed water flows. A positive outcome is that the reduction of discharge of effluent to surface water, as well as the return to more groundwater-fed streams, can improve surface water quality. Lastly, an important consideration for infiltration and groundwater replenishment is suitable soil properties that allow infiltration are required (Bouwer 2002). Large-scale implementation may not be possible in all regions. Overall these considerations demonstrate that groundwater replenishment can be a powerful tool, but that more detailed analysis is needed to understand the balance and impact of these different processes.

Overall, the example scenarios demonstrate the potential impact water reuse can have on the anthropogenic water system if applied at a large scale. Upscaling these applications can provide a significant reduction in the pressure on groundwater. However, in practice, water reuse will always have to be implemented according to the specific requirements of the local situation (fit for purpose) (Capodaglio 2020).

This analysis focuses on cross-sectoral applications of water reuse. Many other applications are possible which are not visualized here, for example within or between industries and grey water reuse by households, businesses or municipalities (Hofman-Caris et al. 2019). In addition, different climate and/or demographic scenarios could be explored. Figures 1 and 2 are based on the yearly averages for the entire Netherlands and illustrate the potential of water reuse between sectors. Future studies and designs of specific cases of water reuse should also include consideration of seasonal water demands and availability. A dynamic model that simulates temporal and spatial variability would be a logical next step from the static Sankey diagrams. However, Sankey diagrams provide a valuable tool to analyse and visualise the propagation of water reuse throughout the water system.

\subsection{Benefits and Risks of Water Reuse - Considerations Regarding Water Quality and Safety}

The Sankey diagrams (Figs. 1 and 2) focus on the quantitative (water volume) aspects of water reuse, with only an generalized measure of water quality specified by arrow colour. Next to that, successful implementation of water reuse requires assessment of the consequences, benefits and risks associated with (large-scale) implementation of water reuse 
(Dingemans et al. 2020). Supplementary Information 3 summarizes the main considerations with regards to water volume, water quality, microbial and chemical risks, purification requirement, legislative requirements, perception and environmental impact for the analysed scenarios. Some important considerations are discussed below:

(I) De-facto reuse of effluent via surface water is common (Beard et al. 2019; Thebo et al. 2017). However, the effect of this practice on agriculture and irrigation is largely undefined. The intentional implementation of water reuse, and controlled safety measures that come with this, can therefore be seen as an improvement over the indirect (unintentional) water reuse.

(II) Discussions are ongoing for an increased purification standard for wastewater in the Netherlands to remove emerging contaminants and e.g. medical residues (Norman 2019). If efforts are applied to improve surface water quality, it can become more attractive to combine this with the implementation of water reuse as part of the required purification already in place. At the same time, reduced emissions of effluent to surface water may help to achieve the improvement of surface water quality (Eggen et al. 2014). These aspects and mutual benefits can work in synergy if the entire water system is considered.

(III) The safety of water reuse depends strongly on the wastewater quality, potential chemicals and biological risks (pathogens) and the specific source used (Dingemans et al. 2020). Consensus on the risk assessment approach and which hazards to include is yet to be established. Several academic risk assessments have been published (e.g. Delli Compagni et al. 2020; Masciopinto et al. 2020), while formal guidelines are pending. Specific issues to consider include the potential impact of recirculation and accumulation of substances that are not removed in treatment and the potential formation of toxic transformation products (WHO 2006; Schindler Wildhaber et al. 2015). WWTP effluent contains pathogens from human waste, which may lead to microbial safety concerns for which adequate safety mechanisms and controls should be in place to minimize risks (WHO 2015). The potential spread of antimicrobial resistant (AMR) bacteria and genes via WWTP effluent should be further investigated and minimized. These considerations have to be taken into account when designing the purification system, and appropriate monitoring should be in place to ensure the integrity of this system while in operation (Rizzo et al. 2013; Alygizakis et al. 2019). In general, the quality requirements of (reused) water are determined by its intended use and application method and potential exposure routes for humans and the environment (e.g. consumers, workers, and the potential transfer to the surrounding environment), and thus the purification system can be designed accordingly (Fischer et al. 2019). In agriculture, safety considerations also depend on the type of crop that is produced and the irrigation method that is applied, which are highlighted in different regulations (Narain et al 2020). Similar considerations are relevant in industry, and also depend on which step in the production water is used and the degree of exposure. Many legal, industrial and trade regulations and guidelines exist for various uses that address risks for consumers, workers and the environment, e.g. WHO (2006), Global G.A.P., ARBO, Drinkwaterbesluit (Dutch drinking water policy). These are based on current water sources and applications and guidelines, and may need to be revisited in order to allow responsible and safe wastewater reuse. 
(IV) In cases with groundwater replenishment and subsurface storage (reuse case D in this study), subsurface passage reduces the microbial risks as pathogens can be filtered out by the soil (Schijven et al. 2003). However, this filtering capacity largely depends on the natural/microbial degradation potential during storage (Stevik et al. 2004; Levantesi et al. 2010), and the impact of infiltration of water types other than rain and surface water on soil and groundwater quality should be investigated further.

(V) The feasibility of building a sufficient water treatment system to purify water to the standard needed will depend on costs and energy demand. This may be assisted by eliminating unnecessary treatment and minimizing long-range conveyance (Capodaglio, 2020).

(VI) Lastly, management of concentrated waste streams produced by some water treatment systems is still a major challenge that needs to be addressed.

\subsection{Boundary Conditions - Consideration Regarding Regulation and Perception}

Regulation around water reuse is complex and differs between water type and application (SI 2) (Dingemans et al. 2020; Shoushtarian and Negahban-Azar 2020). The responsibility of parties regarding the validation and routine monitoring of the wastewater quality, integrity of the purification system, and guaranteeing the supplied water meets quality and safety standards consistently, urges the need for optimization of water reuse governance. An increased need and sense of urgency, as modelled in the STOOM scenario in this study, may trigger adoption of supportive regulations or integration in national legislation. For the reuse scenario of WWTP effluent use for irrigation, the new EU minimum quality requirements provide clarity on procedures (European Commission 2020). For the other scenarios, several different national regulations have to be considered based on the specific situation.

Next to safety and regulatory considerations, the successful implementation of water reuse is dependent on public acceptance and perception. There can be resistance to effluent reuse due to the 'yuck factor' (Smith et al. 2018). Under the current situation, people are often unaware that de facto indirect water reuse already takes place (Beard et al. 2019, Drewes et al. 2017). It is expected that increased public awareness of the flows of treated wastewater in the water system, including the current practice of de facto reuse, will increase acceptance of intended (planned) reuse. In a future scenario where the water system is under pressure, acceptance of water reuse may increase as its benefits (e.g. because of water scarcity) are understood. Health risk perception of the different examples of water reuse is difficult to generalize, but overall acceptance decreases with increasing human contact (Fielding et al. 2019). The inclusion of infiltration and subsurface passage leads to a more positive reception of water reuse, even for drinking water (Van Houtte and Verbauwhede 2013). An essential factor for the acceptance of effluent use is the trust in the organizations involved and their ability to protect public health (Smith et al. 2018).

\subsection{Synthesis}

The Sankey diagrams presented here show that water reuse has the potential to improve water system robustness by decreasing reliance on groundwater on a system level (for the Netherlands) with regards to water volumes. The method presented here provides a 
valuable tool to evaluate the potential of water reuse schemes in a regional context. However, due to the high abstraction level of the approach, assumptions and generalizations have to be made with regards to e.g., water losses and quality demands. This high-level assessment should still be followed by more detailed analysis of e.g. the specific hydrological consequences, safety and water quality requirements, governance, perception, and environmental impact before implementation. The cases presented here provide calculation examples to illustrate the potential of different types of water reuse. In reality, the strategy for a specific region is likely to consist of a combination of water reuse types, traditional water sources, alternative water sources (e.g. rainwater) and water conservation measures.

For the successful integration of water reuse it is essential that the boundary conditions of water quantity, water quality (including purification and waste streams), safety, regulations and perception are met. It can only be determined based on integral considerations whether the implementation of water reuse is a feasible and desirable solution. The water system perspective and visualisations demonstrate that actions taken at one location in the water system (e.g. reuse of effluent for farming or industry) can lead to either positive or negative effects elsewhere (improved water quality, reduced groundwater overexploitation, lower baseflow of effluent fed streams). These actions and effects are distributed between different parties and across different sectors. It is therefore essential to bring different stakeholders together and emphasize the positive effects and mutual benefits that can be gained from collaboration, as well as to identify and address potential downsides in advance. This asks for a regional strategy on improving water system robustness, by implementing water reuse, combined with other measures like rainwater harvesting, spatial planning, water-efficient crops, or zero liquid discharge of sectors. The approach presented here can be used to assess the potential risks and (unintended) propagation of local interventions at other locations in the water system. At a regional scale, it can be used to identify potential synergies in the water system and make connections to find mutual benefits.

Supplementary Information The online version contains supplementary material available at https://doi. org/10.1007/s11269-021-02912-5.

Acknowledgements This work is part of the Joint Research Program of the Dutch and Flemish drinking water companies. The authors thank Kees van Leeuwen for valuable comments and suggestions and Lisa Andrews for textual comments and editing.

Author Contributions All authors contributed to the study conception and design. Framework and methodology (S. F. Stofberg, G. J. Pronk), data analysis: (T. C. G. W. van Dooren, S. F. Stofberg). Discussion and contribution of expertise: M. M. L. Dingemans (toxicology, regulatory aspects), J. Frijns (perception, governance aspects) N. E. Koeman (industry, purification technology) P. W. M. H. Smeets (microbiology, water safety planning), R. P. Bartholomeus (hydrology, agriculture). The first draft of the manuscript was written by G. J. Pronk, T. C. G. W. van Dooren and R. P. Bartholomeus. All authors commented on the text and approved the final version of the manuscript.

Funding This research was funded by the Joint Research Programme of the Dutch and Flemish drinking water companies (BTO).

Data Availability The authors confirm that the data supporting the findings of this study are available within the article or could be requested from the corresponding author, upon reasonable request. All data are publicly accessible at the sources cited in the text.

\section{Declarations}

Conflict of Interests There are no competing interests to declare. 
Open Access This article is licensed under a Creative Commons Attribution 4.0 International License, which permits use, sharing, adaptation, distribution and reproduction in any medium or format, as long as you give appropriate credit to the original author(s) and the source, provide a link to the Creative Commons licence, and indicate if changes were made. The images or other third party material in this article are included in the article's Creative Commons licence, unless indicated otherwise in a credit line to the material. If material is not included in the article's Creative Commons licence and your intended use is not permitted by statutory regulation or exceeds the permitted use, you will need to obtain permission directly from the copyright holder. To view a copy of this licence, visit http://creativecommons.org/licenses/by/4.0/.

\section{References}

Alygizakis NA, Besselink H, Paulus GK, Oswald P, Hornstra LM, Oswaldova M, Medema GJ, Thomaidis NS, Behnisch PA, Slobodnik J (2019) Characterization of wastewater effluents in the Danube River Basin with chemical screening, in vitro bioassays and antibiotic resistant genes analysis. Environ Int 127:420-429. https://doi.org/10.1016/j.envint.2019.03.060

Beard JE, Bierkens MF, Bartholomeus RP (2019) Following the Water: Characterising de facto Wastewater Reuse in Agriculture in the Netherlands. Sustainability 11(21):5936. https://doi.org/10.3390/su11215936

Bontoux J, Courtois G (1996) Wastewater reuse for irrigation in France. Water Sci Technol 33(10-11):4549. https://doi.org/10.1016/0273-1223(96)00405-2

Bouwer H (2002) Artificial recharge of groundwater: hydrogeology and engineering. Hydrogeol J 10(1):121-142. https://doi.org/10.1007/s10040-001-0182-4

Capodaglio AG (2020) Fit-for-purpose urban wastewater reuse: Analysis of issues and available technologies for sustainable multiple barrier approaches. Crit Rev Environ Sci Technol. https://doi.org/10.1080/ 10643389.2020.1763231

CBS Statline (2019) Zuivering van stedelijk afvalwater (in Dutch). CBS. https://opendata.cbs.nl/\#/CBS/nl/. Accessed 22 February 2021

Curmi E, Fenner R, Richards K, Allwood JM, Bajželj B, Kopec GM (2013) Visualising a Stochastic Model of Californian Water Resources Using Sankey Diagrams. Water Resour Manage 27:3035-3050. https:// doi.org/10.1007/s11269-013-0331-2

Dillon P, Stuyfzand PJ, Grischek T et al (2019) Sixty years of global progress in managed aquifer recharge. Hydrogeol J 27(1):1-30. https://doi.org/10.1007/s10040-018-1841-z

De Graaf IEM, Gleeson T, Van Beek LPH, Sutanudjaja EH, Bierkens MFP (2019) Environmental flow limits to global groundwater pumping. Nature 574(7776):90-94. https://doi.org/10.1038/s41586-019-1594-4

Delli Compagni R, Gabrielli M, Polesel F, Turolla A, Trapp S, Vezzaro L, Antonelli M (2020) Risk assessment of contaminants of emerging concern in the context of wastewater reuse for irrigation: An integrated modelling approach. Chemosphere 242:125185. https://doi.org/10.1016/j.chemosphere.2019. 125185 (Epub 2019 Oct 23 PMID: 31689637)

Devaux I, Gerbaud L, Planchon C, Bontoux J, Glanddier PY (2001) Infectious risk associated with wastewater reuse: an epidemiological approach applied to the case of Clermont-Ferrand. France Water Science and Technology 43(12):53-60. https://doi.org/10.2166/wst.2001.0711

Dingemans MML, Smeets PWMH, Medema G, Frijns J, Raat KJ, Van Wezel AP, Bartholomeus RP (2020) Responsible Water Reuse Needs an Interdisciplinary Approach to Balance Risks and Benefits. Water 12(5):1264. https://doi.org/10.3390/w12051264

Drewes JE, Hübner U, Zhiteneva V, Karakurt S (2017) Characterization of unplanned water reuse in the EU. European Commission. http://www.observatorio2030.com/sites/default/files/2019-11/IN_77_2017_VA_ 54_Characterization\%20of\%20unplanned\%20water\%20reuse\%20in\%20the\%20EU_Final\%20Report.pdf. Accessed 22 February 2021

Eggen RIL, Hollender J, Joss A, Schärer M, Stamm C (2014) Reducing the discharge of micropollutants in the aquatic environment: the benefits of upgrading wastewater treatment plants. Environ Sci Technol 48(14):7683-7689. https://doi.org/10.1021/es500907n

European Commission (2020) Regulation (EU) 2020/741 of the European Parliament and of the Council of 25 May 2020 on Minimum Requirements for Water Reuse. Official Journal of the European Union L 177/32: pp. 32-55. https://eur-lex.europa.eu/legal-content/EN/TXT/PDF/?uri=CELEX: 32020R0741\&from=en. Accessed 22 February 2021

Fielding KS, Dolnicar S, Schultz T (2019) Public acceptance of recycled water. Int J Water Resour Dev 35(4):551-586. https://doi.org/10.1080/07900627.2017.1419125

Fischer A, Van Wezel AP, Hollender J, Cornelissen E, Hofman R, Van der Hoek JP (2019) Development and application of relevance and reliability criteria for water treatment removal efficiencies 
of chemicals of emerging concern. Water Res 161:274-287. https://doi.org/10.1016/j.watres.2019. 05.088

Giannoccaro G, Arborea S, De Gennaro BC, Iacobellis V, Piccinni AF (2019) Assessing Reclaimed Urban Wastewater for Reuse in Agriculture: Technical and Economic Concerns for Mediterranean Regions. Water 11(7):1511. https://doi.org/10.3390/w11071511

Graveland C, Baas K, Opperdoes E (2017) Physical water flow accounts with Supply and Use and water asset/water balance assessment NL.CBS. https://www.cbs.nl/-/media/_pdf/2017/38/physical-waterflow-accounts-with-supply-use-and-water-resources-es-2017.pdf. Accessed 22 February 2021

Hochstrat R, Wintgens T, Melin T, Jeffrey P (2006) Assessing the European wastewater reclamation and reuse potential — a scenario analysis. Desalination 188(1-3):1-8. https://doi.org/10.1016/j.desal. 2005.04.096

Hofman-Caris R, Stofberg SF, Van Alphen HJ, De Waal L, Van Huijgevoort M (2019) VO Radicaal nieuwe bronnen voor drinkwater (in Dutch). KWR Water Research Insitute. https://library.kwrwater. nl/publication/59958049/. Accessed 22 February 2021

Hunink J, Delsman J, Prinsen G, Bos-Burgering L, Mulder N, Visser M (2018) Vertaling van Deltascenario's 2017 naar modelinvoer voor het Nationaal Water Model (in Dutch). Deltares. https://edepot. wur.nl/499094. Accessed 22 February 2021

Kloosterman RA, van der Hoek JP, Herder P (2021) Resilient Drinking Water Resources. Water Resour Manage 35:337-351. https://doi.org/10.1007/s11269-020-02736-9

Koeman-Stein NE, Creusen RJM, Zijlstra M, Groot CK, Van den Broek WBP (2016) Membrane distillation of industrial cooling tower blowdown water. Water Resources and Industry 14:11-17. https:// doi.org/10.1016/j.wri.2016.03.002

Kourakos G, Dahlke HE, Harter T (2019) Increasing groundwater availability and seasonal base flow through agricultural managed aquifer recharge in an irrigated basin. Water Resour Res 55(9):74647492. https://doi.org/10.1029/2018WR024019

Levantesi C, La Mantia R, Masciopinto C, Böckelmann U, Ayuso-Gabella MN, Salgot M, Tandoi V, Van Houtte E, Wintgens T, Grohmann E (2010) Quantification of pathogenic microorganisms and microbial indicators in three wastewater reclamation and managed aquifer recharge facilities in Europe. Science of the Total Environment 408(21): 4923-4930. https://doi.org/10.1016/j.scitotenv. 2010.07.042

Liu L, Lopez E, Dueñas-Osorio L et al (2020) The importance of system configuration for distributed direct potable water reuse. Nat Sustain 3:548-555. https://doi.org/10.1038/s41893-020-0518-5

Majamaa K, Aerts PEM, Groot C, Paping LLMJ, Van den Broek W, Van Agtmaal S (2010) Industrial water reuse with integrated membrane system increases the sustainability of the chemical manufacturing. Desalin Water Treat 18(1-3):17-23. https://doi.org/10.5004/dwt.2010.1284

Makropoulos C, Nikolopoulos D, Palmen L, Kools S, Segrave A, Vries D, Koop S, Van Alphen HJ, Vonk E, Van Thienen P, Rozos E, Medema G (2018) A resilience assessment method for urban water systems. Urban Water Journal 15(4):316-328. https://doi.org/10.1080/1573062X.2018.1457166

Masciopinto C, Vurro M, Lorusso N, Santoro D, Haas CN (2020) Application of QMRA to MAR operations for safe agricultural water reuses in coastal areas. Water Res x 19(8):100062. https://doi.org/10. 1016/j.wroa.2020.100062.PMID:32923999;PMCID:PMC7475278

McDonald RI, Green P, Balk D, Fekete BM, Revenga C, Todd M, Montgomery M (2011) Urban growth, climate change, and freshwater availability. Proc Natl Acad Sci USA 108(15):6312-6317. https:// doi.org/10.1073/pnas.1011615108

Metcalf \& Eddy Inc., Tchobanoglous G, Burton FL, Tsuchihashi R, Stensel HD (2013) Wastewater engineering: Treatment and resource recovery (5th ed.). McGraw-Hill Professional

Narain DMB, Bartholomeus RP, Dekker SC, Van Wezel AP (2020) Natural purification through soils: Risks and opportunities of sewage effluent reuse in sub-surface irrigation. In: de Voogt P. (eds) Reviews of Environmental Contamination and Toxicology (Continuation of Residue Reviews). vol 250. Springer, Cham. https://doi.org/10.1007/398_2020_49

Norman (2019) Contaminants of Emerging Concern in Urban Wastewater. Network of reference laboratories, research centres and related organisations for monitoring of emerging environmental substances. https://www.normandata.eu/sites/default/files/files/Publications/Position\%20paper_CECs\% 20UWW_NORMAN_WE_2019_Final_20190910_public.pdf. Accessed 22 February 2021

Partners 4 Urban Water, Deltares (2020) Emissieschattingen Diffuse bronnen EmissieRegistratie: Effluenten RWZI's, regenwaterriolen, niet aangesloten riolen, overstorten en IBA's (in Dutch). Partners 4 Urban Water and Deltares. http://eracceptatie.emissieregistratie.nl/erpubliek/documenten/Water/ Factsheets/Nederlands/Effluenten\%20RWZI\%20(berekend).pdf. Accessed 22 February 2021

Pintilie L, Torres CM, Teodosiu C, Castells F (2016) Urban wastewater reclamation for industrial reuse: An LCA case study. J Clean Prod 139:1-14. https://doi.org/10.1016/j.jclepro.2016.07.209 
Rizzo L, Manaia C, Merlin C, Schwartz T, Dagot C, Ploy MC, Michael I, Fatta-Kassinos D (2013) Urban wastewater treatment plants as hotspots for antibiotic resistant bacteria and genes spread into the environment: a review. Sci Total Environ 447:345-360. https://doi.org/10.1016/j.scitotenv. 2013.01.032

Schijven JF, De Bruin HAM, Hassanizadeh SM, De Roda Husman AM (2003) Bacteriophages and clostridium spores as indicator organisms for removal of pathogens by passage through saturated dune sand. Water Res 37(9):2186-2194. https://doi.org/10.1016/S0043-1354(02)00627-9

Schindler Wildhaber Y, Mestankova H, Schärer M, Schirmer K, Salhi E, Von Gunten U (2015) Novel test procedure to evaluate the treatability of wastewater with ozone. Water Res 75:324-335. https:// doi.org/10.1016/j.watres.2015.02.030

Shoushtarian F, Negahban-Azar M (2020) Worldwide regulations and guidelines for agricultural water reuse: a critical review. Water 12:971. https://doi.org/10.3390/w12040971

Smith HM, Brouwer S, Jeffrey P, Frijns J (2018) Public responses to water reuse - Understanding the evidence. J Environ Manage 207:43-50. https://doi.org/10.1016/j.jenvman.2017.11.021

Stevik TK, Aa K, Ausland G, Hanssen JF (2004) Retention and removal of pathogenic bacteria in wastewater percolating through porous media: a review. Water Res 38(6):1355-1367. https://doi.org/10. 1016/j.watres.2003.12.024

Stofberg SF, Hofman-Caris CHM, Pronk GJ, Van Alphen HJ, Putters B (2019) Toekomstverkenning: alternatieve bronnen voor drinkwater in Nederland (in Dutch). H2O-Online. https://www.h2owaternetwerk. nl/vakar tikelen/toekomstverkenning-alternatieve-bronnen-voor-drinkwater-in-nederland. Accessed 22 February 2021

Ternes TA, Bonerz M, Herrmann N, Teiser B, Andersen HR (2007) Irrigation of treated wastewater in Braunschweig, Germany: An option to remove pharmaceuticals and musk fragrances. Chemosphere 66(5):894-904. https://doi.org/10.1016/j.chemosphere.2006.06.035

Thebo AL, Drechsel P, Lambin EF, Nelson KL (2017) A global, spatially-explicit assessment of irrigated croplands influenced by urban wastewater flows. Environmental Research Letters 12(7): 074008. https:// iopscience.iop.org/article/https://doi.org/10.1088/1748-9326/aa75d1/meta. Accessed 22 February 2021

Van der Aa NGFM, Tangena BH, Wuijts S, De Nijs ACM (2015) Scenario's drinkwatervraag 2040 en beschikbaarheid bronnen: Verkenning grondwatervoorraden voor drinkwater (in Dutch). RIVM. https:// rivm.openrepository.com/handle/10029/557188. Accessed 22 February 2021

Van Houtte E, Cauwenberghs J, Weemaes M, Thoeye C, Kazner C, Wintgens T, Dillon P (2012) Water reclamation technologies for safe managed aquifer recharge. IWA Publishing, London

Van Houtte E, Verbauwhede J (2013) Long-time membrane experience at Torreele's water re-use facility in Belgium. Desalin Water Treat 51(22-24):4253-4262. https://doi.org/10.1080/19443994.2013. 769487

Vewin (2017) Drinkwaterstatistieken 2017. Vewin. https://www.vewin.nl/SiteCollectionDocuments/ Publicaties/Cijfers/Drinkwaterstatistieken-2017-NL.pdf. Accessed 22 February 2021

Vreeburg JHG, Vloerbergh IN, Van Thienen P, De Bont R (2013) Shared failure data for strategic asset management. Water Science \& Technology: Water Supply 13(4):1154-1160. https://doi.org/10. 2166/ws.2013.111

Vörösmarty CJ, Green P, Salisbury J, Lammers RB (2000) Global water resources: vulnerability from climate change and population growth. Science 289(5477):284-288. https://doi.org/10.1126/science.289. 5477.284

WHO (2006) Guidelines for the safe use of wastewater, excreta and greywater (Volume IV: Excreta and greywater use in agriculture). World Health Organization. https://www.who.int/water_sanitation_ health/publications/gsuweg4/en/. Accessed 22 February 2021

WHO (2015) Sanitation Safety Planning: Manual for Safe Use and Disposal of Wastewater Greywater and Excreta. World Health Organization. https://apps.who.int/iris/handle/10665/171753. Accessed 22 February 2021

Wolters HA, Van den Born GJ, Dammers E, Reinhard S (2018) Deltascenario's voor de 21e eeuw: Actualisering 2017 (in Dutch), Deltares. https://media.deltares.nl/deltascenarios/Deltascenarios_ actualisering2017_achtergrondrapport.pdf. Accessed 22 February 2021

Zuurbier KG, Smeets P, Roest K, Van Vierssen W (2018) Use of Wastewater in Managed Aquifer Recharge for Agricultural and Drinking Purposes: The Dutch Experience. Safe Use of Wastewater in Agriculture. Springer, Cham. https://doi.org/10.1007/978-3-319-74268-7_8

Publisher's Note Springer Nature remains neutral with regard to jurisdictional claims in published maps and institutional affiliations. 